\title{
Effects of Feeding a Mycotoxin Binder on Nutrient Digestibility, Alkaloid Recovery in Feces, and Performance of Lambs Fed Diets Contaminated with Cereal Ergot
}

\author{
Kim Stanford ${ }^{1, *(1)}$, Mary Lou Swift ${ }^{2}$, Yuxi Wang ${ }^{3}$ (D) , Tim A. McAllister ${ }^{3}$, John McKinnon ${ }^{4}$, \\ Barry Blakley ${ }^{5}$ and Alex V. Chaves ${ }^{6}$ (iD \\ 1 Livestock Research Section, Alberta Agriculture and Forestry, Lethbridge, AB T1J 4V6, Canada \\ 2 Department of Agriculture, Food and Nutritional Sciences, University of Alberta, Edmonton, AB T6G 2P5, \\ Canada; MaryLou.Swift@trouwnutrition.com \\ 3 Agriculture and Agri-Food Canada, Lethbridge Research and Development Centre, Lethbridge, AB T1J 4B1, \\ Canada; yuxi.wang@agr.gc.ca (Y.W.); tim.mcallister@agr.gc.ca (T.A.M.) \\ 4 Department of Animal and Poultry Science, University of Saskatchewan, Saskatoon, SK S7N 5B4, Canada; \\ john.mckinnon@usask.ca \\ 5 Department of Veterinary Biomedical Sciences, University of Saskatchewan, Saskatoon, SK S7N 5A8, \\ Canada; brb237@mail.usask.ca \\ 6 School of Life and Environmental Sciences, University of Sydney, Sydney 2006, NSW, Australia; \\ alex.chaves@sydney.edu.au \\ * Correspondence: kim.stanford@gov.ab.ca; Tel.: +1-403-381-5150
}

Received: 29 May 2018; Accepted: 30 July 2018; Published: 1 August 2018

\begin{abstract}
As contamination with cereal ergot has been increasing in western Canada, this study evaluated impacts of feeding a mycotoxin binder (Biomin ${ }^{\circledR} \mathrm{II}$; BB) on nutrient digestibility, alkaloid recovery in feces, and lamb growth performance. Forty-eight ram lambs $(25.9 \pm 1.4 \mathrm{~kg})$ were randomly assigned to one of four barley-based diets: Control (C), no added alkaloids, Control $+\mathrm{BB}$ fed at $30 \mathrm{~g} /$ head per day (CBB); Ergot, $2564 \mathrm{ppb}$ total $R+S$ epimers (E); Ergot $+\mathrm{BB}, 2534 \mathrm{ppb} R+S$ epimers (EBB). Lambs were fed ab libitum for up to 11 weeks until slaughter at $>46 \mathrm{~kg}$ live weight. Both average daily gain $(\mathrm{ADG})$ and gain/feed ratio were greater $(p<0.01)$ for lambs fed $\mathrm{C}$ and $\mathrm{CBB}$ diets as compared with those containing added ergot, although dry matter intake was not affected by dietary ergot or BB. Serum prolactin concentrations were two times higher in EBB- compared with E-fed lambs $(p<0.05)$, although both were lower than in C or CBB $(p<0.001)$ lambs. Rectal temperatures were greater in lambs receiving dietary ergot $(p \leq 0.001)$ than in C-and CBB-fed lambs. In a digestibility study using eight ram lambs, treatment with $\mathrm{BB}$ increased neutral detergent fiber (NDF) digestibility $(p=0.01)$. Nitrogen retention ( $g$ ) was greater $(p<0.05)$ for lambs receiving $C$ or CBB compared with ergot-contaminated diets. Feces of EBB lambs had 38.5\% greater $(p<0.001)$ recovery of alkaloids compared with those fed E. Based on sparing of prolactin, BB may reduce impacts of ergot alkaloids by increasing their excretion in feces. Accordingly, concentrations of dietary alkaloids, which would not harm sheep, would be increased by feeding BB.
\end{abstract}

Keywords: cereal ergot; mycotoxin binder; lamb performance; nutrient digestibility

Key Contribution: Feeding the mycotoxin binder to lambs increased excretion of ergot alkaloids in feces by $38.5 \%(p<0.001)$ and increased serum prolactin concentrations compared with lambs fed ergot-contaminated diets without the binder. Accordingly, the binder shows promise for alleviating some negative impacts of cereal ergot alkaloids, although nitrogen metabolism and growth performance were not restored. 


\section{Introduction}

Over the past 15 years, contamination of cereal grains with ergot has markedly increased in western Canada [1]. Consequently, livestock have been increasingly exposed to a number of alkaloids produced by Claviceps purpurea fungi, including ergocornine, ergocristine, ergocryptine, ergotamine, ergometrine, ergosine, and corresponding $S$ epimers [2]. Common symptoms of exposure of livestock to ergot alkaloids are diverse and may include a reduction in feed intake and/or reduced growth performance [3], decreased serum prolactin [4], agalactia [5], vasoconstriction leading to impaired thermoregulation [6], gangrenous extremities [4], reduced fetal growth [7], and abortion [8]. Multiple alkaloids are generally present simultaneously in livestock feeds, although individual ergot bodies may not contain all alkaloids [9]. Toxic effects of alkaloids may be additive [10], synergistic [11], or less than additive [12]. As a further complication, alkaloids may interconvert between the more-biologically active $R$ and the less-active $S$ epimers [13].

Strategies to reduce impacts of mycotoxins, such as ergot alkaloids on livestock, range from preventing fungal infections through crop rotations and selecting crop varieties that resist infection [14] to applying a variety of physical or chemical treatments to the grain after it is contaminated. Grain cleaning techniques have largely eliminated ergotism as a human disease [6], but this process concentrates ergot in the grain screenings that are used as livestock feed. Binders that adsorb mycotoxins to their surface and prevent their absorption in the digestive tract are another harm-reduction strategy [15], but they may also adversely affect absorption of vitamins, minerals, or antibiotics [16]. Binders are most commonly clays or yeast-derivatives [17] and may also contain enzymatic components for biotransformation and detoxification of mycotoxins [18], as well as growth promoters or immune enhancers [15].

Binding capacity varies with the physical and chemical nature of the adsorbent (total charge, charge distribution, pore size) and the characteristics of the mycotoxin (polarity, solubility, shape, and charge distribution) [19]. Adsorption agents have been useful for preventing aflatoxicosis, but results for other mycotoxins have been more variable [20]. To our knowledge, in vivo use of binders for ergot alkaloids has not been studied, although several in vitro studies have shown promise [21,22]. As in vivo studies evaluating the ability of binders to reduce negative impacts of ergot alkaloids are limited, the objective of the present study was to evaluate growth performance, nutrient digestion and recovery of ergot alkaloids in feces of lambs fed pelleted diets containing a mycotoxin binder.

\section{Results}

\subsection{Alkaloid Concentrations and Profiles}

Concentration of total and individual alkaloids did not differ between Control (no added alkaloids, C) and Control + Biomin ${ }^{\circledR}$ II (BB) (fed at $30 \mathrm{~g} /$ head/day; CBB) or between Ergot (2564 ppb total alkaloids; E) and Ergot + BB (2533 ppb total alkaloids; EBB) diets (Table 1). Accordingly, adding the alkaloid binder to diets did not influence the analysis of $R$ or $S$ epimers in the diets.

Table 1. Mean concentrations of alkaloid $R$ and $S$ epimers (ppb) in experimental diets fed to lambs. C-Control; CBB-Control + BB; E-Ergot; EBB-Ergot + BB.

\begin{tabular}{|c|c|c|c|c|c|c|c|c|}
\hline \multirow{2}{*}{ Alkaloid } & \multicolumn{2}{|c|}{$\mathrm{C}$} & \multicolumn{2}{|c|}{$\mathrm{CBB}^{1}$} & \multicolumn{2}{|c|}{ E } & \multicolumn{2}{|c|}{ EBB } \\
\hline & $R$ Epimer & $S$ Epimer & $R$ Epimer & $S$ Epimer & $R$ Epimer & $S$ Epimer & $R$ Epimer & $S$ Epimer \\
\hline Chanoclavin & 0 & & 0 & & 1 & & 1 & \\
\hline Ergocornine/inine & 1 & 0 & 10 & 2 & 106 & 79 & 104 & 77 \\
\hline Ergocristine/inine & 4 & 1 & 6 & 2 & 915 & 246 & 985 & 260 \\
\hline Ergotcryptine/inine & 0 & 0 & 0 & 0 & 159 & 70 & 140 & 65 \\
\hline Ergometrine/inine & 0 & 1 & 3 & 1 & 321 & 3 & 292 & 4 \\
\hline Ergosine/inine & 0 & 0 & 0 & 0 & 149 & 47 & 151 & 41 \\
\hline Ergotamine/inine & 1 & 0 & 10 & 1 & 419 & 50 & 369 & 44 \\
\hline Total epimers & 6 & 2 & 29 & 6 & 2070 & 494 & 2042 & 491 \\
\hline Total alkaloids & \multicolumn{2}{|c|}{8} & \multicolumn{2}{|c|}{36} & \multicolumn{2}{|c|}{2564} & \multicolumn{2}{|c|}{2533} \\
\hline
\end{tabular}

${ }^{1}$ Biomin ${ }^{\circledR} \mathrm{II}$ (BB), containing diatomaceous earth, kaolin, plant and yeast extracts, esterase, and epoxidase, fed at $30 \mathrm{~g} /$ head per day. 


\subsection{Nutrient Digestion by Lambs}

Although digestibility of dry matter (DM), organic matter (OM), crude protein $(\mathrm{CP})$, and acid detergent fiber (ADF) was not affected by dietary ergot or BB, digestibility of neutral detergent fiber (NDF) was higher $(p=0.01)$ in lambs fed BB compared with those fed diets without BB (Table 2). The BB did not negatively impact nutrient digestibility or N metabolism, as other than higher NDF digestibility, effects of $\mathrm{BB}$ were not significant $(p>0.17)$. Intake of $\mathrm{N}$ and $\mathrm{N}$ output did not differ among diets, but nitrogen retention $(\mathrm{g})$ increased $(p<0.05)$ in lambs receiving control diets $(\mathrm{C}, \mathrm{CBB})$ as compared with those receiving diets containing added ergot (E, EBB). Similarly, N retained as a percentage of intake and percentage of $\mathrm{N}$ retained of that digested averaged $4.9 \%$ greater $(p<0.05)$ in lambs receiving diets without added ergot. Concentrations of alkaloids in feces of lambs fed C or CBB were below detectable limits (Table 3 ). For diets with added ergot, BB increased $(p<0.001)$ recovery of $R$ epimers in feces from an average of $2.6 \%$ of that consumed in lambs receiving $E$ to $3.6 \%$ for lambs fed EBB. Effects of BB were consistent for all individual alkaloids, with each showing greater recovery $(p<0.001)$ in feces from lambs fed EBB.

Table 2. Nutrient digestion and nitrogen metabolism in lambs $(n=8)$ comparing diets with or without added ergot and the presence or absence of a mycotoxin binder (treatment).

\begin{tabular}{|c|c|c|c|c|c|c|c|c|c|}
\hline \multirow[b]{2}{*}{ Digestibility \% } & \multicolumn{2}{|c|}{ Diet $^{1}$} & \multicolumn{2}{|c|}{ Treatment $^{1}$} & \multirow[b]{2}{*}{ SEM $^{2}$} & \multicolumn{4}{|c|}{ Probability } \\
\hline & C, CBB & E, EBB & C, E & CBB, EBB & & Diet & Treat & Period & Diet $\times$ Treat \\
\hline Dry matter & 72.6 & 72.0 & 72.1 & 72.4 & 0.5 & 0.43 & 0.65 & 0.19 & 0.94 \\
\hline Organic matter & 74.8 & 72.0 & 72.1 & 72.4 & 0.5 & 0.40 & 0.18 & 0.16 & 0.92 \\
\hline Crude protein & 74.8 & 74.1 & 73.9 & 75.0 & 0.6 & 0.89 & 0.88 & 0.01 & 0.66 \\
\hline Neutral detergent fiber & 46.3 & 46.0 & 44.2 & 48.1 & 0.8 & 0.79 & 0.01 & 0.25 & 0.01 \\
\hline $\begin{array}{l}\text { Acid detergent fiber } \\
\text { N metabolism }\end{array}$ & 27.3 & 29.0 & 27.6 & 28.7 & 1.1 & 0.30 & 0.49 & 0.27 & 0.83 \\
\hline $\mathrm{N}$ intake, $\mathrm{g}$ & 45.8 & 45.7 & 45.9 & 45.7 & 1.1 & 0.97 & 0.91 & $<0.001$ & 0.58 \\
\hline $\mathrm{N}$ digested, $\mathrm{g}$ & 32.7 & 32.8 & 32.8 & 32.8 & 0.8 & 0.93 & 0.98 & $<0.001$ & 0.53 \\
\hline $\mathrm{N}$ retained, $\mathrm{g}$ & 11.2 & 9.4 & 10.3 & 10.3 & 0.5 & 0.02 & 0.93 & 0.02 & 0.32 \\
\hline N output, g & 35.6 & 36.6 & 36.4 & 35.8 & 1.1 & 0.52 & 0.71 & $<0.001$ & 0.84 \\
\hline$\%$ of $\mathrm{N}$ retained (intake) & 25.3 & 21.2 & 23.3 & 23.1 & 1.1 & 0.02 & 0.90 & $<0.001$ & 0.50 \\
\hline$\%$ of $\mathrm{N}$ retained (digested) & 35.4 & 29.7 & 32.6 & 32.4 & 1.4 & 0.01 & 0.95 & $<0.001$ & 0.54 \\
\hline
\end{tabular}

${ }^{1} \mathrm{C}$, no added alkaloids; CBB no added alkaloids + mycotoxin binder fed at $30 \mathrm{~g} /$ head per day; E, $2564 \mathrm{ppb}$ total alkaloids ( $R+S$ epimers); EBB, 2533 ppb total alkaloids + mycotoxin binder. ${ }^{2}$ SEM, standard error of the mean

Table 3. Recovery (\%) of individual $R$ epimers in feces of lambs $(n=8)$ fed diets with or without added ergot in the presence or absence of a mycotoxin binder.

\begin{tabular}{cccccccc}
\hline \multicolumn{9}{c}{ Diet $^{1}$} \\
\hline Alkaloid & $\mathrm{C}^{2}$ & $\mathrm{CBB}^{2}$ & $\mathrm{E}$ & EBB & SEM & Diet & Period \\
Ergocornine & $0^{\mathrm{a}}$ & $0^{\mathrm{a}}$ & $2.3^{\mathrm{b}}$ & $3.1^{\mathrm{c}}$ & 0.1 & $<0.001$ & 0.85 \\
Ergocristine & $0^{\mathrm{a}}$ & $0^{\mathrm{a}}$ & $0.8^{\mathrm{b}}$ & $1.0^{\mathrm{c}}$ & 0.05 & $<0.001$ & 0.60 \\
Ergocryptine & $0^{\mathrm{a}}$ & $0^{\mathrm{a}}$ & $4.5^{\mathrm{b}}$ & $7.0^{\mathrm{c}}$ & 0.3 & $<0.001$ & 0.58 \\
Ergometrine & $0^{\mathrm{a}}$ & $0^{\mathrm{a}}$ & $0.6^{\mathrm{b}}$ & $0.8^{\mathrm{c}}$ & 0.04 & $<0.001$ & 0.93 \\
Ergosine & $0^{\mathrm{a}}$ & $0^{\mathrm{a}}$ & $2.5^{\mathrm{b}}$ & $3.1^{\mathrm{c}}$ & 0.07 & $<0.001$ & 0.23 \\
Ergotamine & $0^{\mathrm{a}}$ & $0^{\mathrm{a}}$ & $4.9^{\mathrm{b}}$ & $6.6^{\mathrm{c}}$ & 0.1 & $<0.001$ & 0.31 \\
\hline
\end{tabular}

a,b,c Means in a row with different superscripts differ $(p<0.001) .{ }^{1} \mathrm{C}$, no added alkaloids; CBB no added alkaloids + mycotoxin binder fed at $30 \mathrm{~g} /$ head per day; E, $2564 \mathrm{ppb}$ total alkaloids ( $R+S$ epimers); EBB, $2533 \mathrm{ppb}$ total alkaloids + mycotoxin binder. ${ }^{2}$ For both $\mathrm{C}$ and CBB diets, alkaloids in feces below limit of detection.

\subsection{Lamb Performance, Serum Prolactin, Rectal Temperature, and Carcass Characteristics}

Initial live weight (LW), final LW, and dry matter intake (DMI) were not affected by dietary ergot or by BB (Table 4), although both average daily gain (ADG) and feed conversion (gain/feed) were greater $(p<0.05)$ in lambs receiving $\mathrm{C}$ or $\mathrm{CBB}$ as compared with those receiving diets containing added ergot. Adding BB to diets increased serum prolactin concentrations of lambs $(p=0.05)$, with that of lambs fed EBB two times higher than that of lambs fed E. However, prolactin concentrations of EBB 
lambs remained lower $(p<0.001)$ than those of C-and CBB-fed lambs. Average rectal temperature was highest in lambs fed diets with added ergot $(p<0.05)$, but the difference between those and $C$ and $\mathrm{CBB}$ lambs were small $\left(0.26^{\circ} \mathrm{C}\right)$. Adding ergot to diets or adding BB did not affect hot carcass weight, dressing percentage or grade rule (GR) measurement.

Table 4. Growth performance, rectal temperature $\left({ }^{\circ} \mathrm{C}\right)$, and carcass characteristics of lambs compared diets with or without added ergot and the presence or absence of a mycotoxin binder (treatment). Lambs received experimental diets for 6 to 11 weeks.

\begin{tabular}{|c|c|c|c|c|c|c|c|c|}
\hline Parameter & \multicolumn{2}{|c|}{ Diet $^{1}$} & \multicolumn{2}{|c|}{ Treatment $^{1}$} & SEM & \multicolumn{3}{|c|}{ Probability } \\
\hline \multicolumn{9}{|c|}{ Growth $(n=47)$} \\
\hline Initial body weight (kg) & 25.9 & 25.8 & 25.9 & 25.8 & 1.4 & 0.98 & 0.98 & 0.79 \\
\hline Final body weight (kg) & 48.1 & 48.0 & 48.5 & 47.6 & 0.6 & 0.89 & 0.64 & 0.71 \\
\hline Dry matter intake (g/day) & 1470.6 & 1430.7 & 1454.2 & 1446.7 & 43.3 & 0.35 & 0.86 & 0.18 \\
\hline $\mathrm{LN}^{2}$ serum prolactin $(\mu \mathrm{g} / \mathrm{L})$ & 5.33 & 2.18 & 3.48 & 4.03 & 0.14 & $<0.001$ & 0.05 & 0.32 \\
\hline Rectal temperature ${ }^{\circ} \mathrm{C}$ & 39.12 & 39.38 & 39.28 & 39.22 & 0.07 & $<0.001$ & 0.41 & 0.34 \\
\hline \multicolumn{9}{|c|}{ Carcass characteristics $(n=35)$} \\
\hline Hot carcass weight (kg) & 21.1 & 20.9 & 21.1 & 20.8 & 0.3 & 0.64 & 0.54 & 0.73 \\
\hline Dressing percentage & 43.2 & 42.8 & 43.1 & 42.9 & 0.7 & 0.57 & 0.78 & 0.34 \\
\hline
\end{tabular}

${ }^{1} \mathrm{C}$, no added alkaloids; CBB no added alkaloids + mycotoxin binder fed at $30 \mathrm{~g} /$ head per day; E, $2564 \mathrm{ppb}$ total alkaloids ( $R+S$ epimers); EBB, $2533 \mathrm{ppb}$ total alkaloids + mycotoxin binder. ${ }^{2} \mathrm{LN}$, normal log.

\section{Discussion}

\subsection{Alkaloid Concentrations and Profiles}

The recommended dosage of $\mathrm{BB}$ ranges from 15 to $30 \mathrm{~g} /$ head per day, depending on concentrations of mycotoxins in the feed [23]. As alkaloid concentrations in the diets with added ergot approached the allowable limits for Canadian sheep [24], a dosage of $30 \mathrm{~g} / \mathrm{head}$ per day was used. If BB had interfered with measurement of alkaloids in diets, the results of the current study would have been less clear. Fortunately, concentrations of individual epimers and total alkaloids were similar for dietary treatments with or without BB, likely because the alkaloid extraction protocol freed the bound alkaloids. Total alkaloid concentrations of diets with added ergot were similar to the highest concentration used in a previous study [12]. However, even though the same source of ergot-contaminated screenings was used in both studies, concentrations of individual alkaloids differed, a reflection of the variability in concentrations of alkaloids in individual ergot bodies [9]. Compared with the previous study, the most marked changes in alkaloid concentrations included ergotamine $(+43 \%)$, ergocristine $(+35 \%)$, ergocryptine $(-31 \%)$, and ergometrine $(-20 \%)$. Consequently, while total alkaloid concentrations were similar across the two studies, changes in alkaloid profiles likely contributed to differences in animal responses between the present and our previous study [12].

\subsection{Nutrient Digestibility}

Both NDF and ADF digestibility were linearly reduced with increasing ergot alkaloid concentration in our previous study, where lambs were fed up to $432 \mathrm{ppb} R$ epimers [25]. However, no changes in nutrient digestibility were noted by Coufal-Majewski et al. [12] using the same source and concentration of contaminated screenings as this study. Accordingly, as digestibility of NDF was impacted in the present study only by BB and not by dietary ergot, ergot alkaloids appear to inconsistently influence fiber digestibility. Differences among lambs, variability in alkaloid profiles and concentrations between studies, or a combination of these factors is likely responsible for the observed inter-study variation. Alkaloids present in tall fescue seed have been shown to inhibit fiber digestion 
in sheep [26], although ergovaline, the primary alkaloid present in tall fescue, is not prevalent in cereal ergot [27].

Impacts of mycotoxin binders on nutrient digestibility may be affected by the types of mycotoxins present. Dänicke et al. [28] suggested that BB depressed fiber digestion in lambs exposed to Fusarium-contaminated wheat. In contrast, we found that BB improved NDF digestibility in lambs fed CBB or EBB diets. Currently, BB contains proprietary plant extracts designed to compensate for adverse conditions in the gastrointestinal tract created by mycotoxins [29] in addition to bentonites and diatomaceous earth, which can adsorb polar mycotoxins [30]. As a result of the multiple constituents of $\mathrm{BB}$, it was not possible to determine which ingredients were responsible for improving NDF digestibility. The BB did not negatively impact nutrient digestibility or $\mathrm{N}$ metabolism. Accordingly, BB meets a primary requirement for a mycotoxin binder in that it did not impair nutrient absorption [19].

A lower $\mathrm{N}$ retention in lambs fed diets containing added ergot was not noted in our previous lamb study [12], although reduced digestibility of protein has been reported in pigs receiving diets containing $4.7 \mathrm{ppm}$ total ergot alkaloids [ $R+S$ epimers] [3]. Impacts of alkaloids on $\mathrm{N}$ metabolism in other studies using pigs have varied depending on the concentrations [31] and types of alkaloids [3]. Regardless of overall impacts of ergot alkaloids on N metabolism, BB did not improve N retention, which was lower in lambs fed diets with added ergot as compared with those receiving C or CBB. In contrast, Kiyothong et al. [30] found that BB improved digestibility of crude protein and NDF in dairy cattle fed diets contaminated with a mixture of Fusarium mycotoxins. Many Fusarium mycotoxins contain a highly-reactive epoxide group that is directly involved in their toxicity [15], while ergot alkaloids do not contain a comparable functional group. As both expoxidase and binding components of BB would target Fusarium mycotoxins, it is not surprising that effectiveness of BB is influenced by the type of mycotoxin present.

Mycotoxin binders have been developed primarily to adsorb mycotoxins and prevent their absorption in the gastro-intestinal tract [14], and we are unaware of previous in vivo studies that have examined their ability to bind ergot alkaloids. In the present study, BB increased excretion of $R$ epimers in feces by an average of $38.5 \%$, although excretion varied by alkaloid and ranged from 0.6 to $7.0 \%$ of the individual alkaloids consumed. Alkaloid recovery in feces was lower than that reported in our previous study [12], but was similar to the $5 \%$ recovery of fescue alkaloids in sheep feces reported by others [32].

\subsection{Animal Performance, Rectal Temperature, and Serum Prolactin}

In the present study, lambs fed diets containing added ergot had reduced ADG as compared with those fed C or CBB, with similar reductions in ADG noted for lambs receiving $2447 \mathrm{ppb}$ total alkaloids [12]. Negative responses to dietary ergot in the present study also included reduced feed conversion efficiency, a result similar to that reported for diets containing $432 \mathrm{ppb} R$ epimers [25]. However, BB did not improve the ADG or gain/feed in EBB lambs.

Feed intake by lambs in this and our previous studies has been consistently unaffected by cereal ergot, an observation that contrasts to studies with chickens [33] and pigs [3], but is similar to those with calves [34]. Feed intake has been improved, along with performance measures in some studies of BB in dairy cattle fed diets contaminated with Fusarium [30], but not in dairy cattle receiving diets contaminated with aflatoxins [29]. Similar to the present study, BB neither increased feed intake nor performance measures in a study of pigs receiving diets contaminated with Fusarium mycotoxins [35]. The BB has received EU registration based on its capacity to bind aflatoxin [23], but its utility may vary with the type of mycotoxin, although similarities in the binding of aflatoxin and ergopeptine alkaloids in vitro have been reported [36]. The BB was chosen for evaluation in the present study because of its binding constituents, including kaolin clay, as previous in vitro studies had demonstrated binding of ergot alkaloids to a variety of clays $[21,22,36]$. In contrast to the ergot alkaloid binders previously evaluated in vitro, BB was available in Canada and licensed for use in Canadian feeds, enabling slaughter of the lambs through conventional channels. 
Lambs receiving diets contaminated with fescue alkaloids have previously been shown to have increased rectal temperatures and reduced serum prolactin concentrations [37], similar to E and EBB lambs in this study. Increased rectal temperatures after exposure to ergot are thought to be related to alkaloid-induced vasoconstriction interfering with the capacity for thermoregulation $[4,6,37]$. Although increased rectal temperatures in lambs fed ergot were small, lambs were housed in a ventilated barn and thermal stress to lambs may have been increased if they had been kept in outdoor pens, as would be typical of commercial lamb production. Increased body temperatures and other symptoms of inflammation have been linked to immune responses of pigs exposed to Fusarium mycotoxins [38]. Accordingly, differences in the immune status of animals and existing extent of inflammation prior to consumption of contaminated feed may possibly explain the variation in animal responses to ergot alkaloids and other mycotoxins [39]. Lambs in the present study were healthy, which may explain their relatively limited responses to high concentrations of alkaloids.

In our previous studies with lambs, serum prolactin concentrations were a better predictor of the impact of ergot on growth than were dietary concentration of alkaloids. Prolactin concentration has already been identified as a suitable indicator for exposure to fescue alkaloids [4]. That EBB lambs had increased serum prolactin concentrations demonstrates that $\mathrm{BB}$ reduced the impact of alkaloids through increased fecal excretion. The sparing effect of $\mathrm{BB}$ on prolactin is important as it confirms that the mycotoxin binder directly reduced the negative physiological impacts of the alkaloids as opposed to acting as a non-specific growth promoter.

Concentrations of alkaloids in E and EBB were high, approaching the maximum allowable in diets for Canadian sheep [24]. As BB did not improve growth performance or feed conversion efficiency, the costs for feeder lambs would outweigh benefits. Perhaps greater concentrations of BB would improve $\mathrm{N}$ retention and growth performance, but greater concentrations may also lead to the binding of nutrients [19]. Based on the sparing effect on prolactin and improved NDF digestibility noted in EBB as compared with E-fed lambs, BB may have more utility for breeding animals receiving high-forage diets. Conditions such as agalactia are directly related to inhibition of prolactin secretion in animals exposed to ergot alkaloids [40], but the ability of BB to prevent this economically-devastating condition, or otherwise protect breeding ruminants from negative impacts of ergot alkaloids requires further investigation. As BB increased excretion of alkaloids in feces, adding BB to diets for sheep would increase the concentration of alkaloids, which could be fed without causing harm, although breakpoints would have to be established for feeder lambs as compared with breeding stock, which may also be affected by the alkaloid profile of the contaminated feed.

\section{Materials and Methods}

All experiments were conducted between June and September 2017 at the Lethbridge Research Centre (LRC) of Agriculture and Agri-Food Canada. Protocol \#1507 was reviewed and approved on 29 October 2016 by the LRC Animal Care Committee according to the guidelines of the Canadian Council on Animal Care [41].

\subsection{Ergot Source, Alkaloid Determination}

Ergot-contaminated barley screenings were sourced from a previous study [12] in which similar concentrations of screenings were included in the diet. To prepare diets, screenings were ground through a $1 \mathrm{~mm}$ screen using a Wiley ${ }^{\circledR}$ Cutting Mill (Thomas Scientific, Swedesboro, NJ, USA). Ground screenings were substituted for barley and four different pelleted diets were made each in a single batch (2500 kg; Table 5). The mycotoxin binder (Biomin ${ }^{\circledR}$ II, Biomin Canada Inc., Mont-St.-Hillaire, QC, Canada) contained diatomaceous earth, kaolin clay, yeast and plant extracts, and enzymes targeted for the degradation of zearalenones and trichothecenes. Diets were Control (C; no added alkaloids); Control $+\mathrm{BB}$ fed at $30 \mathrm{~g} /$ head per day; $\mathrm{CBB}$ ); $\operatorname{Ergot}(2564 \mathrm{ppb}$ total $R+S$ epimers; E); and Ergot (2534 ppb total $R+S$ epimers + BB fed at $30 \mathrm{~g} /$ head per day; EBB; Table 1). The BB was added to the appropriate diets prior to pelleting. During the course of the study, a $500 \mathrm{~g}$ sample 
of each diet was collected and analyzed four times for thirteen ergot alkaloids (i.e., chanoclavine, ergocornine, ergocorninine, ergocristine, ergocristinine, ergocryptine, ergocryptinine, ergometrine, ergometrinine, ergosine, ergosinine, ergotamine, and ergotaminine) by Biomin Research Center (Tulln, Austria) using HPLC-MS/MS [42]. A subsample (5.0 g) of the diet was ground through a 1-mm screen and stored at room temperature overnight in $20 \mathrm{~mL}$ of extraction solvent (acetonitrile/water/acetic acid 79:20:1, $v / v / v)$ in the dark. Samples were then extracted for $90 \mathrm{~min}$ and centrifuged for $2 \mathrm{~min}$ at $1500 \times g$. The pellet was discarded and $350 \mu \mathrm{L}$ aliquots of the supernatant was then diluted with solvent (acetonitrile/water/acetic acid 79:20:1, $v / v / v$ ) and mixed. A total of $5 \mu \mathrm{L}$ of extracted alkaloids was then injected into an Agilent 1290 HPLC (Aligent Technologies Inc., Waldbronn, Germany) combined with an Applied Biosystems 5500 QTrap mass spectrometer. Chromatographic separation was performed at $25{ }^{\circ} \mathrm{C}$ on a Gemini ${ }^{\circledR} \mathrm{C}_{18}$-column, $150 \times 4.6 \mathrm{~mm}$ internal diameter, $5 \mu \mathrm{m}$ particle size equipped with a $\mathrm{C}_{18}$ security guard cartridge, $4 \times 3 \mathrm{~mm}$ internal diameter (Pheomenex, Torrance, CA, USA).

Table 5. Diet composition.

\begin{tabular}{|c|c|c|c|c|}
\hline Ingredients, $\mathrm{g} / \mathrm{kg}$ & $\mathrm{C}$ & CBB & $\mathrm{E}$ & EBB \\
\hline Barley grain & 540.0 & 520.0 & 537.5 & 517.5 \\
\hline Alfalfa pellets $(18 \% \mathrm{CP})$ & 270.0 & 270.0 & 270.0 & 270.0 \\
\hline Canola meal & 168.0 & 168.0 & 168.0 & 168.0 \\
\hline Limestone & 3.0 & 3.0 & 3.0 & 3.0 \\
\hline Sheep Mineral ${ }^{1}$ & 10.0 & 10.0 & 10.0 & 10.0 \\
\hline Vitamin A, D, E 2 & 0.25 & 0.25 & 0.25 & 0.25 \\
\hline $\operatorname{Deccox}^{3}$ & 0.132 & 0.132 & 0.132 & 0.132 \\
\hline Ergot screening & 0.0 & 0.0 & 2.52 & 2.52 \\
\hline Canola oil & 10.0 & 10.0 & 10.0 & 10.0 \\
\hline Biomin ${ }^{\circledR} \mathrm{II}^{4}$ & 0.0 & 20.0 & 0.0 & 20.0 \\
\hline \multicolumn{5}{|c|}{ Dry matter (DM) and chemical composition (g/kg, Analytical DM basis) } \\
\hline Organic matter & $925.5( \pm 1.3)$ & $919.1( \pm 0.3)$ & $926.3( \pm 1.5)$ & $917.5( \pm 3.0)$ \\
\hline Crude protein $(\mathrm{CP})$ & $190.5( \pm 14.5)$ & $194.8( \pm 8.4)$ & $191.3( \pm 43.5)$ & $193.7( \pm 32.5)$ \\
\hline Neutral detergent fiber & $264.7( \pm 104.6)$ & $256.7( \pm 88.4)$ & $257.9( \pm 32.0)$ & $280.2( \pm 30.2)$ \\
\hline Acid detergent fiber & $121.2( \pm 11.1)$ & $124.0( \pm 12.0)$ & $127.3( \pm 23.2)$ & $130.4( \pm 24.0)$ \\
\hline
\end{tabular}

${ }^{1}$ Sheep mineral constitutes (\%): salt 92.6 , potassium magnesium sulfate 4.979 , zinc sulfate 0.921 , magnesium sulfate 0.835 , organic iodine $0.014,1 \%$ selenium premix 0.143 , cobalt carbonate 0.004 , canola oil $0.398 .{ }^{2}$ Vitamin ADE constitutes: vitamin A 10,000,000 IU, vitamin D 1,000,000 IU, vitamin E 10,000 IU $/ \mathrm{kg} .{ }^{3}$ Deccox active ingredient: decoquinate (6\%; Zoetis, Kirkland, QC, Canada). ${ }^{4}$ Biomin ${ }^{\circledR}$ II (BB) includes kaolin clay, yeast extracts, diatomaceous earth, plant extracts, esterase, and epoxidase. No other clay-based pellet binder included in diets.

\subsection{Nutrient Digestion and Metabolism of Lambs}

Eight newly-weaned Canadian Arcott $\times$ Rideau Arcott ram lambs that had not been previously exposed to dietary ergot were selected based on similar initial LW $(20.5 \pm 0.49 \mathrm{~kg})$, to estimate the digestibility of the diets using a cross-over design. Each of the four periods lasted 21 day, with 14 day for adaption and 7 day of sample collection. Lambs were fed once daily, and based on the previous 4 day of intake were restricted to $95 \%$ of ad libitum intake during the week of total collection. Health of lambs was visually monitored daily. Lambs were shorn and pre-fitted with strap-on canvas fecal collection bags 7 day prior to the first collection. During collections, lambs were individually fed in crates with transparent panels, which allowed visual contact with the other lambs and minimized stress. Feces and urine were collected daily in the last 4 day of each period and analyzed for DM, OM, $\mathrm{CP}, \mathrm{NDF}$, and ADF as described by Coufal-Majewski et al. [25]. Samples of each diet (500 g) were collected during each of the four periods and analyzed for the same constituents, as were feces and urine. Dried ground subsamples (500 g) of feces collected in each period from each diet were also analyzed for ergot alkaloid $R$ epimers. 


\subsection{Performance Study}

Forty-eight newly-weaned ram lambs were blocked by weight and randomly assigned to one of the four diets (Table 5). Lambs were individually fed and received both feed and water ad libitum, with orts and feed consumed determined daily. Lambs were weighed weekly with rectal temperatures measured at weighing using a digital thermometer (GLA M750, GLA Agricultural Electronics, San Luis Obispo, CA, USA). Ambient temperature in the barn was also recorded three times daily during the study. Blood samples were collected by venipuncture from 36 lambs at $35 \mathrm{~kg}$ body weight (BW), and at slaughter weight ( $\geq 46 \mathrm{~kg}$ ). Lambs chosen for prolactin analyses received experimental diets for at least three weeks prior to the initial blood collection, with an interval of at least three weeks between bleedings. Larger lambs, which were $>30 \mathrm{~kg}$ at initiation of the study, were excluded from prolactin analyses. Serum was obtained by centrifugation $\left(2000 \times \mathrm{g}\right.$ for $15 \mathrm{~min}$ at $\left.4{ }^{\circ} \mathrm{C}\right)$ and stored in $1 \mathrm{~mL}$ screw-cap tubes in duplicate at $-80{ }^{\circ} \mathrm{C}$. Prolactin concentrations were then determined in serum using a double antibody radioimmunoassay as described by Coufal-Majewski et al. [25].

Lambs remained on feed over a period of 6 to 11 weeks until reaching slaughter weight. Thirty-five lambs were shipped to a commercial abattoir for slaughter (Sungold Meats, Innisfail, AB, Canada) with hot carcass weight, dressing percentage, and grade rule (GR) measurement determined according to standards of the Canadian Food Inspection Agency [43]. Lamb health and well-being was monitored several times daily and one lamb was removed from the study as a result of urinary calculi.

\subsection{Statistical Analyses}

Digestibility and nitrogen metabolism estimates were analyzed by two-way analysis of variance (ANOVA) using the MIXED procedure of SAS (SAS Inst. Inc., Cary, NC, USA) in a crossover design with diet (control vs. ergot) and treatment (control vs. BB) as fixed effects and lamb within diet $\times$ treatment as a random effect. For the performance study, initial live weight, final live weight, ADG, feed efficiency, serum prolactin, and carcass data were analyzed as a completely randomized design with diet (control vs. ergot) and treatment (control vs. BB) as a fixed effects and lamb within diet $\times$ treatment as a random effect. Average daily gain was determined by dividing weight gain (initial LW-final LW) by the number of days in the study. Feed efficiency was calculated as the ratio between ADG and DMI ( $g$ of live weight gain/g DMI). Prolactin data were normalized by log transformation prior to analyses. A repeated measures analysis was used for DMI analyses, with week as the repeated variable and lamb within diet $\times$ treatment a random effect. Treatment means were compared using the least squares mean (LSMEANS) linear hypothesis test of SAS (SAS Inst. Inc., Cary, NC, USA). Significance for all analyses was declared at $p \leq 0.05$.

Author Contributions: Conceptualization, K.S., T.A.M., B.B., and J.M.; Methodology, M.L.S., J.M., Y.W., T.A.M., and B.B.; Formal Analysis, A.V.C.; Writing-Original Draft Preparation, K.S.; Writing-Review \& Editing, K.S., T.A.M., B.B., and A.V.C.; Project Administration, K.S. and Y.W.; Funding Acquisition, K.S. and M.L.S.

Funding: This research was funded by Alberta Livestock and Meat Agency and the Strategic Research and Development Program of Alberta Agriculture and Forestry (grant \# 2015R030R) and Alberta Lamb Producers.

Conflicts of Interest: The authors declare no conflict of interest. The funders had no role in the design of the study; in the collection, analyses, or interpretation of data; in the writing of the manuscript; and in the decision to publish the results.

\section{References}

1. Tittlemier, S.A.; Drul, D.; Roscoe, M.; McKendry, T. Occurrence of ergot and ergot alkaloids in western Canadian wheat and other cereals. J. Agric. Food Chem. 2015, 63, 6644-6650. [CrossRef] [PubMed]

2. European Food Safety Authority. Scientific opinion on ergot alkaloids in food and feed. EFSA J. $2012,10$. [CrossRef]

3. Mainka, S.; Dänicke, S.; Böhme, H.; Ueberschär, K.-H.; Polten, S.; Hüther, L. The influence of ergot-contaminated feed on growth and slaughtering performance, nutrient digestibility and carry over or ergot alkaloids in growing-finishing pigs. Arch. Anim. Nutr. 2005, 59, 377-395. [CrossRef] [PubMed] 
4. Klotz, J.L. Activities and effects of ergot alkaloids on livestock physiology and production. Toxins 2015, 7, 2801-2821. [CrossRef] [PubMed]

5. Diekman, M.A.; Green, M.L. Mycotoxins and reproduction in domestic livestock. J. Anim. Sci. 1992, 70, 1615-1627. [CrossRef] [PubMed]

6. Craig, A.M.; Klotz, J.L.; Duringer, J.M. Cases of ergotism in livestock and associated ergot alkaloid concentrations in feed. Front. Chem. 2015. [CrossRef] [PubMed]

7. Duckett, S.K.; Andrae, J.G.; Pratt, S.L. Exposure to ergot alkaloids during gestation reduces fetal growth in sheep. Front. Chem. 2014. [CrossRef] [PubMed]

8. Greatorex, J.C.; Mantle, P.G. Effect of rye ergot on pregnant sheep. J. Reprod. Fertil. 1974, 37, 33-41. [CrossRef] [PubMed]

9. Gruisie, T.; Cowan, V.; Singh, J.; McKinnon, J.; Blakley, B. Correlation and variability between weighing, counting and analytical methods to determine ergot (Claviceps purpurea) contamination of grain. World Mycotoxin J. 2017, 10, 209-218. [CrossRef]

10. Guerre, P. Ergot alkaloids produced by endophytic fungi of the genus Epichlö̈. Toxins 2015, 7, 773-790. [CrossRef] [PubMed]

11. Dänicke, S.; Diers, S. Effects of ergot alkaloids in feed on performance and liver function of piglets evaluated by the ${ }^{13}$ C-methacetin breath test. Arch. Anim. Nutr. 2013, 67, 15-36. [CrossRef] [PubMed]

12. Coufal-Majewski, S.; Stanford, K.; McAllister, T.A.; Wang, Y.; Blakley, B.; McKinnon, J.; Swift, M.L.; Chaves, A.V. Effects of continuously feeding diets containing increasing concentrations of cereal ergot alkaloids on nutrient digestibility, alkaloid recovery in feces and performance traits of ram lambs. Toxins 2017, 9. [CrossRef]

13. Krska, R.; Crews, C. Significance, chemistry and determination of ergot alkaloids: A review. Food Addit. Contam. 2008, 25, 722-731. [CrossRef] [PubMed]

14. Binder, E.M. Managing the risk of mycotoxins in modern feed production. Anim. Feed Sci. Technol. 2007, 133, 149-166. [CrossRef]

15. Vanhoutte, I.; Audenaert, K.; De Gelder, L. Biodegradation of mycotoxins: Tales from known and unexplored worlds. Front. Microbiol. 2016, 7. [CrossRef] [PubMed]

16. De Mil, T.; Devreese, M.; De Saeger, S.; Eeckhout, M.; De Backer, P.; Croubels, S. Influence of mycotoxin binders on the oral bioavailability of doxycycline in pigs. J. Agric. Food Chem. 2016, 64, 2120-2126. [CrossRef] [PubMed]

17. Bryden, W.L. Mycotoxin contamination of the feed supply chain: Implications for animal productivity and feed security. Anim. Feed Sci. Technol. 2012, 173, 134-158. [CrossRef]

18. Patriarca, A.; Fernandez Pinto, V. Prevalence of mycotoxins in foods and decontamination. Curr. Opin. Food Sci. 2017, 14, 50-60. [CrossRef]

19. Avantaggiato, G.; Solfrizzo, M.; Visconti, A. Recent advances on the use of adsorbent materials for detoxification of Fusarium mycotoxins. Food Addit. Contam. 2005, 22, 379-388. [CrossRef] [PubMed]

20. Stoev, S.D. Food safety and increasing hazard of mycotoxin occurrence in foods and feeds. Crit. Rev. Food Sci. Nutr. 2013, 53, 887-901. [CrossRef] [PubMed]

21. Huebner, H.J.; Lemke, S.L.; Ottinger, S.E.; Mayra, K.; Phillips, T.D. Molecular characterization of high affinity, high capacity clays for the equilibrium sorption of ergotamine. Food Addit. Contam. 1999, 16, 159-171. [CrossRef] [PubMed]

22. Malysheva, S.V.; Di Mavungu, J.D.; Schoeters, E.; Larionova, L.; Goryacheva, I.Y.; De Sager, S. Rapid and sensitive LC-MS/MS determination of ergot alkaloids in buffered solutions: Application to in vitro testing of a clay-based mycotoxin binder. World Mycotoxin J. 2013, 6, 105-115. [CrossRef]

23. Vila-Donat, P.; Marin, S.; Sanchis, V.; Ramos, A.J. A review of mycotoxin adsorbing agents, with an emphasis on their multi-binding capacity for animal feed decontamination. Food Chem. Toxicol. 2018. [CrossRef] [PubMed]

24. Canadian Food Inspection Agency. Section 1: Mycotoxins in Livestock Feed. Available online: http:/ / www.inspection.gc.ca/animals / feeds/regulatory-guidance/rg-8/eng/1347383943203/ 1347384015909? chap=0 (accessed on 24 January 2018).

25. Coufal-Majewski, S.; Stanford, K.; McAllister, T.A.; Wang, Y.; Blakley, B.; McKinnon, J.; Chaves, A.V. Effects of pelleting diets containing cereal ergot alkaloids on nutrient digestibility, growth performance and carcass traits of lambs. Anim. Feed Sci. Technol. 2017, 230, 103-113. [CrossRef] 
26. Hannah, S.M.; Paterson, J.A.; Williams, J.E.; Kerley, M.S.; Miner, J.L. Effects of increasing dietary levels of endophyte-infected tall fescue seed on diet digestibility and ruminal kinetics in sheep. J. Anim. Sci. 1990, 68, 1693-1701. [CrossRef] [PubMed]

27. Coufal-Majewski, S.; Stanford, K.; McAllister, T.; Blakley, B.; McKinnon, J.; Chaves, A.V.; Wang, Y. Impacts of cereal ergot in food animal production. Front. Vet. Sci. 2016. [CrossRef] [PubMed]

28. Dänicke, S.; Gädeken, D.; Ueberschär, K.-H.; Meyer, U.; Scholz, H. Effects of Fusarium toxin contaminated wheat and of a detoxifying agent on performance of growing bulls, on nutrient digestibility and on the carry-over of zearalenone. Arch. Anim. Nutr. 2002, 56, 245-261. [CrossRef]

29. Pietri, A.; Bertuzzi, T.; Piva, G.; Binder, E.M.; Schatzmayr, D.; Rodrigues, I. Aflatoxin transfer from naturally-contaminated feed to milk of dairy cows and the efficacy of a mycotoxin deactivating product. Int. J. Dairy Sci. 2009, 4, 34-42.

30. Kiyothong, K.; Rowlinson, P.; Wanapat, M.; Khampa, S. Effect of mycotoxin deactivator product supplementation on dairy cows. Anim. Prod. Sci. 2012, 52, 832-841. [CrossRef]

31. Whittemore, C.T.; Macer, R.C.F.; Miller, J.K.; Mantle, P.G. Some consequences of the ingestion by young and growing pigs or feed contaminated with ergot. Res. Vet. Sci. 1976, 20, 61-69. [PubMed]

32. Westendorf, M.L.; Mitchell, G.E.; Tucker, R.E.; Bush, L.P.; Petroski, R.J.; Powell, R.G. In vitro and in vivo ruminal and physiological responses to endophyte-infected tall fescue. J. Dairy Sci. 1993, 76, 555-563. [CrossRef]

33. Dänicke, S. Ergot alkaloids in fattening chickens (broilers): Toxic effects and carry over depending on dietary fat proportion and supplementation with non-starch polysaccharide (NSP) hydrolyzing enzymes. Toxins 2017, 9, 118. [CrossRef] [PubMed]

34. Schumann, B.; Dänicke, S.; Hübner, S.; Ueberschär, K.H.; Meyer, U. Effects of different levels of ergot in concentrate on the health and performance of male calves. Mycotoxin Res. 2007, 23, 43-55. [CrossRef] [PubMed]

35. Van Le Thanh, B.; Lessard, M.; Chorfi, Y.; Guay, F. The efficacy of anti-mycotoxin feed additives in preventing the adverse effects of wheat naturally contaminated with Fusarium mycotoxins on performance, intestinal barrier function and nutrient digestibility and retention in weanling pigs. Can. J. Anim. Sci. 2015, 95, 197-209. [CrossRef]

36. Tomasevic-Canovic, M.; Sakovic, A.; Rottinghaus, G.; Matijasevic, S.; Duricic, M. Surfactant modified zeolites-New efficient adsorbents for mycotoxins. Microporous Mesoporous Mater. 2003, 61, 173-180. [CrossRef]

37. Gadberry, M.S.; Denard, T.M.; Spiers, D.E.; Piper, E.L. Effects of feeding ergovaline on lamb performance in a heat stress environment. J. Anim. Sci. 2003, 81, 1538-1545. [CrossRef] [PubMed]

38. Tesch, T.; Bannert, E.; Kluess, J.; Frahm, J.; Hüther, L.; Kersten, S.; Breves, G.; Renner, L.; Kahlert, S.; Rothkötter, H.-J.; et al. Relationships between body temperatures and inflammation indicators under physiological and pathophysiological conditions in pigs exposed to system lipopolysaccharides and dietary dioxynivalenol. J. Anim. Physiol. Anim. Nutr. 2018, 102, 241-251. [CrossRef] [PubMed]

39. Pierron, A.; Alassane-Kpembi, I.; Oswald, I.P. Impact of mycotoxin on immune response and consequences for pig health. Anim. Nutr. 2016, 2, 63-68. [CrossRef] [PubMed]

40. Schaar, C.J.; Clemens, J.A. Inhibition of lactation and prolactin secretion in rats by ergot alkaloids. Endocrinology 1972, 90, 285-288. [CrossRef] [PubMed]

41. Canadian Council on Animal Care. CCAC Guidelines on: The Care and Use of Farm Animals in Research, Teaching and Testing; Canadian Council on Animal Care: Ottawa, ON, Canada, 2009.

42. Malachová, A.; Sulyok, M.; Beltrán, E.; Berthiller, F.; Krska, R. Optimization and validation of a quantitative liquid chromatography-tandem mass spectrometric method covering 295 bacterial and fungal metabolites including all regulated mycotoxins in four model food matrices. J. Chromatogr. A 2014, 1362, 45-156. [CrossRef] [PubMed]

43. Government of Canada. Meat Inspection Regulations. Available online: http://laws-lois.justice.gc.ca/eng/ regulations /SOR-90-288/page-10.html\#h-21 (accessed on 11 May 2018).

(C) 2018 by the authors. Licensee MDPI, Basel, Switzerland. This article is an open access article distributed under the terms and conditions of the Creative Commons Attribution (CC BY) license (http:/ / creativecommons.org/licenses/by/4.0/). 